\title{
Hensin, a New Collecting Duct Protein Involved in the In Vitro Plasticity of Intercalated Cell Polarity
}

\author{
Jiro Takito, Chinami Hikita, and Qais Al-Awqati \\ Departments of Medicine and Physiology, College of Physicians and Surgeons of Columbia University, New York, New York 10032
}

\begin{abstract}
Two forms of intercalated cells are present in kidney collecting tubules, the $\alpha$ cell has apical endocytosis, apical $\mathrm{H}^{+}$ATPase and basolateral band 3, while $\beta$ cells have reversed polarity of these proteins and no apical endocytosis. When a $\beta$ cell line was seeded at high density, it changed into the $\alpha$ form. We previously showed that a partially purified 230 $\mathrm{kD}$ extracellular matrix protein of high density cells was able to retarget band 3 from apical to basolateral domains and stimulated apical endocytosis in vitro (Van Adelsberg, J., J.C. Edwards, J. Takito, B. Kiss, and Q. Al-Awqati. 1994. Cell. 76:1053-1061). We now purify this protein, which was named hensin, to near homogeneity and find that it belongs to the macrophage scavenger receptor cysteine rich (SRCR) family. An antibody, generated against a fusion protein made from a partial cDNA recognized a 230$\mathrm{kD}$ protein in rabbit kidney and in the intercalated cell line. In vitro, the hensin antibody inhibited expression of apical endocytosis. Hensin was secreted in a polarized manner and bound to the basolateral membrane and extracellular matrix. Immunohistochemistry of the kidney showed that it was expressed only in collecting tubules. Double immunofluorescence with hensin and peanut lectin, $\mathrm{H}^{+}$-ATPase, or band 3 showed many patterns; most $\alpha$-cells had hensin staining while $50 \%$ of $\beta$-cells did not. These results suggest that hensin may also be involved in the polarity reversal of intercalated cells in vivo. (J. Clin. Invest. 1996. 98:23242331.) Key words: rabbit kidney $\bullet \mathrm{pH}$ homeostasis • extracellular matrix $\bullet$ band $3 \cdot \mathrm{H}^{+}$-ATPase
\end{abstract}

\section{Introduction}

Transport of $\mathrm{H}^{+}$and $\mathrm{HCO}_{3}^{-}$by the collecting tubules of the kidney is one of the major mechanisms by which the kidney regulates the acid-base balance of the body fluids. In the cortical and outer medullary segments of this tubule there are two cell types, principal and intercalated. Only the latter, accounting for about a third of the cells, is responsible for acid-base transport $(1,2)$. While many nephron segments acidify their lumens, the cortical collecting tubule of rabbits usually secretes

\footnotetext{
Address correspondence to Qais Al-Awqati, Departments of Medicine and Physiology, Columbia University, 630 West 168th Street, New York, NY 10032. Phone: 212-305-3512; FAX: 212-305-3475.

Received for publication 13 May 1996 and accepted in revised form 4 September 1996.
}

J. Clin. Invest.

(C) The American Society for Clinical Investigation, Inc. 0021-9738/96/11/2324/08 \$2.00

Volume 98, Number 10, November 1996, 2324-2331
$\mathrm{HCO}_{3}^{-}$. However, treatment of the animals with an acid diet reverses the secretion of alkali to that of acid (for review see reference 3).

Based on purely mophological criteria, it had been known that the intercalated cells were present in at least two forms (4). Using a combination of cell $\mathrm{pH}$, endocytosis and lectin binding we initially found that the intercalated cells exist in two functional forms, one that secretes $\mathrm{H}^{+}$while the other secretes $\mathrm{HCO}_{3}^{-}$into the lumen (5). In the acid-secreting type (here termed $\alpha$ ) a proton translocating ATPase is packaged in endocytic vesicles and is inserted into the apical membrane by a vigorous process of apical endocytosis and exocytosis. Pumping of $\mathrm{H}^{+}$results in the accumulation of cellular $\mathrm{HCO}_{3}^{-}$which is then transported across the basolateral membrane by a $\mathrm{Cl}^{-}$: $\mathrm{HCO}_{3}^{-}$exchanger that is an alternatively spliced form of the red cell anion exchanger, band $3(6,7)$. The alkali secreting cell ( $\beta$ type), has a basolateral proton translocating ATPase and an apical $\mathrm{Cl}^{-}: \mathrm{HCO}_{3}^{-}$exchanger, but no apical endocytosis. We had suggested that the mechanism by which the tubule converts its alkali secretion to that of acid was due to a reversal of the polarity of these proteins in the $\beta$ intercalated cell; a process we termed plasticity in epithelial polarity (5).

Since that proposal, several investigators developed immunocytochemical reagents to examine the polarized distribution of the ATPase and band 3, and the results have suggested that there is a much greater heterogeneity of types of intercalated cells than previously recognized (for review see reference 3 ). While "canonical" $\alpha$ and $\beta$ cells exist, many others had their $\mathrm{H}^{+}$-ATPase or band 3 in vesicles that were distributed diffusely in the cytoplasm or were localized to one or another pole of the cell $(8,9)$. In the most comprehensive of such studies, Bastani et al. analyzed quantitatively the distribution of the $\mathrm{H}^{+}$-ATPase in the rat kidney under various acid-base states (10). As many as seven patterns were recognized and the "population density" of each of these patterns was found to change with acidosis or alkalosis. Since the total number of intercalated cells did not change with acid-base changes, it follows that the changes in the pattern reflect some degree of conversion of one cell type to another. However, these studies were not interpreted within the framework of the plasticity of epithelial polarity.

To test the plasticity model rigorously, we generated an immortalized cell line of the $\beta$-intercalated cell which exhibited all of the known characterstics of this cell. These included transepithelial $\mathrm{HCO}_{3}^{-}$secretion by an apical $\mathrm{Cl}^{-}: \mathrm{HCO}_{3}^{-}$exchanger, basolateral $\mathrm{H}^{+}$-ATPase, apical peanut lectin binding, and no apical endocytosis $(11,12)$. When these clonal cells were seeded at subconfluent density and allowed to grow to confluence, they secreted $\mathrm{HCO}_{3}^{-}$by an apical band 3 (13). However, when they were seeded at high density, they reversed their polarity to that of the $\alpha$ type, secreting $\mathrm{H}^{+}$into the apical medium by a $\mathrm{H}^{+}$-ATPase that is actively endocytosed and exocytosed. In addition, band 3 reversed its polarity from the apical 
to the basolateral membrane. We found that high density cells secreted a factor into the extracellular matrix which was capable of reversing the polarity of low density cells. The ECM (extracellular matrix) fraction was enriched in a protein of 230 $\mathrm{kD}$ and another of $45 \mathrm{kD}$. Partially purified $230 \mathrm{kD}$ protein stimulated endocytosis and reversed the polarity of band 3 in low density cells. Because retargeting of one protein (band 3 ) to the basolateral membrane was associated with induction of endocytosis on the opposite membrane, we suggested that extracellular cues were capable of reorganizing the targeting machinery of the cell (14).

In the present study, we purify this protein to near homogeneity and provide preliminary sequence of its purified peptides which show that it is a previously unidentified protein. Because of its role in the determination of intercalated cell type, we term this protein hensin, from the Japanese, for "change in body" or metamorphosis. It belongs to a newly identified family of proteins, the SRCR (scavenger receptor cysteine rich) family $(15,16)$. While the function of the SRCR domain is not entirely clear, it appears to mediate protein-protein interaction. In addition, we find that this protein is a secreted protein that is basolaterally targeted. In the kidney, the protein is restricted to the collecting tubule. Co-localization studies suggest that it has a heterogenous expression in intercalated cells; half of the $\beta$-intercalated cells do not express it, while most of the $\alpha$-intercalated cells are enriched in it. These studies suggest that this protein which plays an important role in the plasticity of intercalated cell polarity in vitro might also have similar functions in vivo.

\section{Methods}

Materials. $\quad$ L- $\left[{ }^{35} \mathrm{~S}\right]$ methionine $(1.2 \mathrm{mCi} / \mathrm{mmol})$ and $\left[\alpha^{-}{ }^{32} \mathrm{P}\right] \mathrm{dCTP}$ were from DuPont-New England Nuclear (Cambridge, MA). Restriction endonucleases were from Boehringer Mannheim (Indianapolis, IN). All other analytical-grade biochemicals were from Sigma Chemical Co. (St. Louis, MO) or Fisher Scientific (Springfield, NJ).

Cell culture. Stock cultures of clone $\mathrm{C}$ of $\beta$-intercalated cells established from rabbit kidney cortex were maintained as described (11-14). The cells were trypsinized and seeded on Costar (Cambridge, MA) polycarbonate filters (pore size $0.4 \mu \mathrm{m}$ ) at a density of $4 \times 10^{4} \mathrm{cells} / \mathrm{cm}^{2}$ (low density) or $2 \times 10^{6} \mathrm{cells} / \mathrm{cm}^{2}$ (high density) and transferred to $40^{\circ} \mathrm{C}$ to inactivate the $\mathrm{T}$ antigen.

Purification and partial amino acid sequence determinations of hensin. Mono-Q column fractions capable of inducing apical endocytosis were obtained from 1.61 of the ECM of clone $\mathrm{C}$ plated at high density as described previously (14). These were first equilibrated with $7 \mathrm{M}$ urea, $0.2 \mathrm{M} \mathrm{NaCl}, 2 \mathrm{mM}$ EDTA, $0.1 \%$ SDS, and $50 \mathrm{mM}$ Tris- $\mathrm{HCl}$ (pH 7.5) and further purified using Superdex HR200 10/30 chromatography. The hensin-rich fractions were combined, electrophoresed on SDS-PAGE and transferred to a PVDF membrane. The $230-\mathrm{kD}$ band was cut out from the membrane and processed for microsequencing. The amino acid sequences obtained were compared to those of GenBank and EMBL using the GCG software package (Genetics Computer Group, Madison, WI).

Generation of hensin antibodies. Using these peptide sequences we cloned a partial cDNA clone by PCR and expressed the recombinant protein in E. coli. Total RNA was prepared from clone $\mathrm{C}$ after plating at high density using the RNAzol B (TEL-TEST, Friendswood, TX). cDNA was reverse transcribed from the total RNA us-

1. Abbreviations used in this paper: ECM, extracellular matrix; PNA, peanut lectin; SRCR, scavenger receptor cysteine rich. ing random primers with the cDNA cycle kit (Invitrogen, La Jolla, CA). RT-PCR was performed with degenerate primers designed from the amino acid sequences obtained as follows: 5'-TCGAATTCTC(G/A)TC(A/G)CAIAC(A/G/T/C)GT(A/G/T/C)CCCCA-3'; 5' TCGAATTCTT(T/C)GGICA(A/G)GGICC(A/G/T/C)GG(A/G/T/ C)CA(A/G)AT-3'; 5 min at $94^{\circ} \mathrm{C} ; 2$ cycles of 1 min denaturation at $94^{\circ} \mathrm{C}, 2$ min annealing at $37^{\circ} \mathrm{C}, 2 \mathrm{~min}$ extension at $72^{\circ} \mathrm{C}$ followed by 30 cycles of $1 \mathrm{~min}$ denaturation of $94^{\circ} \mathrm{C}, 2 \mathrm{~min}$ annealing at $45^{\circ} \mathrm{C}, 2 \mathrm{~min}$ extension at $72^{\circ} \mathrm{C}$; and a final extension of $7 \mathrm{~min}$ at $72^{\circ} \mathrm{C}$. Amplified bands were recovered from agarose gels and cut with EcoRI, cloned into Bluescript SK $(-)$ vector (Stratagene, San Diego, CA) and sequenced. The vector introduced six histidines into the $\mathrm{COOH}$-terminus of the recombinant hensin fusion protein (Qiagen, Chatsworth, CA). A 700-bp clone of hensin was excised from the Bluescript and ligated with $\mathrm{pQE}-50$ and $\mathrm{pQE}-16$ vectors. The recombinant fusion protein (containing the $6 \times$ His tag) was expressed in E. coli and purified using a Ni-NTA resin. Amino acid analysis of the recombinant protein confirmed its deduced composition (data not shown). The recombinant protein was injected into guinea pigs or chickens to generate polyclonal antibodies.

Western blotting and Northern blotting. The ECM fraction was obtained from clone $\mathrm{C}$ plated at high density as described (14). Kidney cortex, medulla, and papilla were cut from frozen rabbit kidney with a razor and homogenized in $10 \mathrm{vol}$ of PBS, $0.1 \%$ Triton X-100, $0.05 \%$ SDS, and $1 \mathrm{mM}$ PMSF with Polytron. The homogenate was centrifuged at $1,000 \mathrm{~g}$ for $10 \mathrm{~min}$ and centrifuged again at $10,000 \mathrm{~g}$ for $10 \mathrm{~min}$. The resulting supernatant was processed for immunoprecipitation. After electrophoresis, proteins were transferred to nitrocellulose membranes in $10 \%$ methanol, $24 \mathrm{mM}$ Tris, $19.3 \mathrm{mM}$ glycine at $0.25 \mathrm{amp}$ for $5 \mathrm{~h}$. Western blotting was performed as described by Harlow and Lane (17). For Northern blotting, total RNA was prepared from clone $\mathrm{C}$ plated on a plastic tissue-culture flask and the frozen rabbit kidney with RNAzol B. Poly $\mathrm{A}^{+}$RNA was purified from the total RNA with Oligotex mRNA kit (Qiagen). Northern blotting was carried out as described (18).

Immunocytochemistry and immunohistochemistry. For immunocytochemistry, clone $\mathrm{C}$ cells were seeded at high density on filters (Costar, diameter $6.5 \mathrm{~mm}$, pore size $0.4 \mu \mathrm{m}$ ) and cultured for $2 \mathrm{~d}$. The cells were fixed with $100 \%$ methanol for $2 \mathrm{~min}$ at room temperature, blocked with $10 \%$ FBS in PBS for $1 \mathrm{~h}$. Then the filter was cut from the cup and incubated with anti-hensin IgG at a dilution of 1:50. IgG was prepared from guinea pig sera using protein A (17). For immunohistochemistry, $10-\mu \mathrm{m}$ cryostat sections from fresh rabbit kidneys were embedded in Tissue-Tek OCT Compound (Miles Laboratories, Elkhart, IN). The sections were fixed with ice-cold $100 \%$ acetone in PBS for 5 min and blocked with $1 \%$ BSA in PBS for $1 \mathrm{~h}$. For double staining, primary antibodies were mixed and incubated with the section in $1 \%$ BSA and PBS for $1 \mathrm{~h}$ at room temperature: hensin antibody dilution at 1:100, undiluted hybridoma medium of E11 (19), IVF 12 dilution at 1:200 (20). Fluorophore-conjugated secondary antibodies (Jackson Immuno Research Inc., West Grove, PA) were used at dilution 1:200-1:400. TRITIC labeled peanut lectin (Sigma Co.) at dilution 1:20 was incubated with the specimens for $10 \mathrm{~min}$ after the secondary antibody incubation (21). Confocal images were collected on a Bio-Rad MRC 600 confocal laser scanning microscope.

Liberation of hensin from membrane vesicles. Clone $\mathrm{C}$ was seeded on a filter at high density and cultured for $6 \mathrm{~d}$. The cells were scraped, homogenized in $250 \mathrm{mM}$ sucrose, $1 \mathrm{mM}$ EDTA, $10 \mathrm{mM}$ Tris- $\mathrm{HCl}$ (pH 8.0), and centrifuged at 1,000 $\mathrm{g}$ for $10 \mathrm{~min}$. The resulting supernatant was centrifuged at $100,000 \mathrm{~g}$ for $1 \mathrm{~h}$ and the pellet was resuspended in $1 \mathrm{mM}$ EDTA and $10 \mathrm{mM}$ Tris- $\mathrm{HCl}$ ( $\mathrm{pH} 8.0)$ and used as the membrane fraction. The membrane was diluted in $500 \mu \mathrm{l}$ of $1 \mathrm{mM}$ EDTA, $10 \mathrm{mM}$ Tris- $\mathrm{HCl}$ (pH 8.0) with $1 \mathrm{M} \mathrm{KCl}, 1 \mathrm{M} \mathrm{KSCN}$, or $0.1 \mathrm{M}$ $\mathrm{Na}_{2} \mathrm{CO}_{3}(\mathrm{pH}$ 11) and passed through 20 times with 26 gauge needle attached to a $1-\mathrm{ml}$ syringe. The supernatant and the precipitate were separated by ultracentrifugation. The sample was analyzed by SDSPAGE on $7.5 \%$ acrylamide gel, and processed for immunoblotting with anti-hensin serum diluted 1:500. 


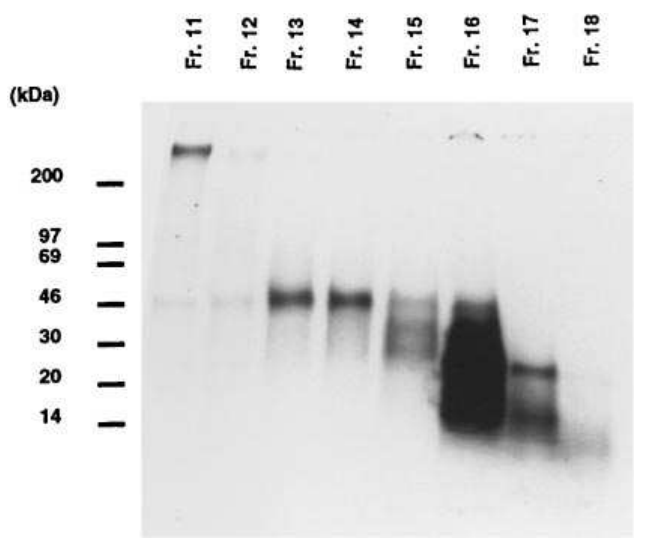

Figure 1. Separation of hensin on gel filtration chromatography. Hensin was extracted from the ECM of the clone $\mathrm{C}$ cell line, purified with gelatin affinity and Mono-Q columns (14). Hensin-enriched fractions obtained by Mono-Q chromatography were further applied on Superdex HR200 10/30 in $7 \mathrm{M}$ urea, $0.2 \mathrm{M} \mathrm{NaCl}, 2$ mM EDTA, 0.1\% $\mathrm{SDS}$ and $50 \mathrm{mM}$ Tris- $\mathrm{HCl}(\mathrm{pH} 7.5)$. The eluate was precipitated with TCA, separated by reduced SDS-PAGE on a 4-20\% acrylamide gradient gel, dried, and then visualized by autoradiography.

\section{Results}

Purification of hensin and sequence of peptides. We previously reported that the extracellular matrix of the intercalated cell line seeded at high density was capable of reversing the polarity of cells seeded at low density (14). Partial purification of the ECM fraction on gelatin sepharose followed by Mono-Q ion exchange chromatography yielded a protein fraction that, by itself reversed the polarity of band 3 in this clone of intercalated cells. This fraction contained a $230-\mathrm{kD}$ protein (hensin) and another $45-\mathrm{kD}$ protein. Sequence of the $45-\mathrm{kD}$ protein showed that it was an intermediate filament of the cytokeratin (Type I.18) (22).

The assay used to follow polarity reversal during chromatographic separation was induction of apical endocytosis, a feature of $\alpha$ - but not $\beta$-intercalated cells. To purify these two proteins further we used several chromatographic resins with no success. Eventually, when these fractions were denatured with

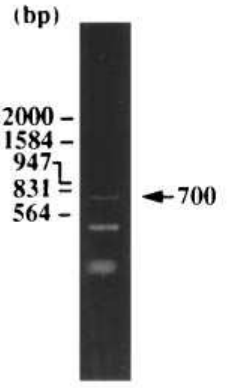

(kDa)
$200-$
97
$69-$
$46-$
$30-$
21 -
$14-$

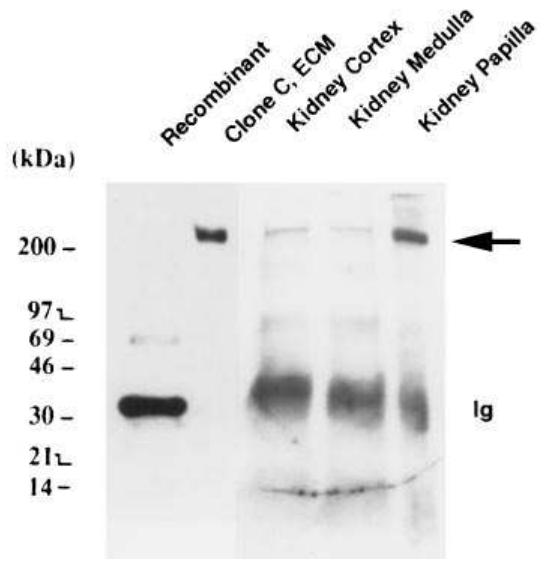

Figure 2. Generation of hensin antibody from a recombinant fusion protein with a 700 bp DNA cloned by RT-PCR. (A) A 700- and 400-bp DNA were cloned by RT-PCR with degenerate primers designed from the amino acid sequences obtained from the purified protein. The PCR products were analyzed on $1.2 \%$ agarose gel, and visualized with ethidium bromide staining. The arrow indicates the position of a 700-bp DNA. (B) Western blotting. Purified recombinant protein $(0.1 \mu \mathrm{g})$ and ECM of clone $\mathrm{C}$ plated at high density were separated on SDS-PAGE, transferred to nitrocellulose, and immunoblotted with antihensin guinea pig serum. Proteins $(1 \mathrm{mg})$ from $10,000 \mathrm{~g}$ supernatant of the cortex, medulla, and papilla were immunoprecipitated with anti guinea pig hensin antibody (dilution 1:500) and processed for immunoblotting with anti-hensin chicken IgY. Signals were detected by ECL system (Amersham International, Buckinghamshire, England). The arrow indicates the position of hensin. The broad bands in kidney cortex, medulla and papilla are Ig crossreacted with anti-chicken IgY secondary antibody.

$7 \mathrm{M}$ urea, and $0.1 \%$ SDS, we obtained a nearly homogenous band of hensin after Superdex 200HR chromatography (Fig. 1). Purified hensin did not induce apical endocytosis. However combinatorial experiments with different fractions separated by the Superdex column also failed to induce endocytosis suggesting that the activity loss was due to irreversible denaturation by the harsh conditions in the final step.

Table I. Hensin Belongs To the SRCR Family of Proteins

\begin{tabular}{|c|c|}
\hline SRCR concensus & R LV - - G - - CEG - VE- - - WGTV - CD - - W - - - - VVC \\
\hline Hensin-1 & VEIYHGGR \\
\hline Hensin-2 & GSWGTV CDDSWDINDASVVC \\
\hline SRCR consensus & R - LGCG - G- - F - C - G - E - SL \\
\hline Hensin-3 & -QLGCGMAVSAPGSAR \\
\hline Hensin-4 & -QLGCGWAVSAPGSAR \\
\hline Hensin-5 & -QLGCGT A VSAPGSAR \\
\hline Hensin-6 & FGQGPGQIVLDDVSCSGQEL \\
\hline Hensin-7 & $\underline{\text { FGQGPGQIVLDDVSCSGQEPYL }}$ \\
\hline \multicolumn{2}{|c|}{ Unassigned sequences } \\
\hline Hensin-8 & GSFTSSNFLR \\
\hline Hensin-9 & FVSCDSI \\
\hline
\end{tabular}




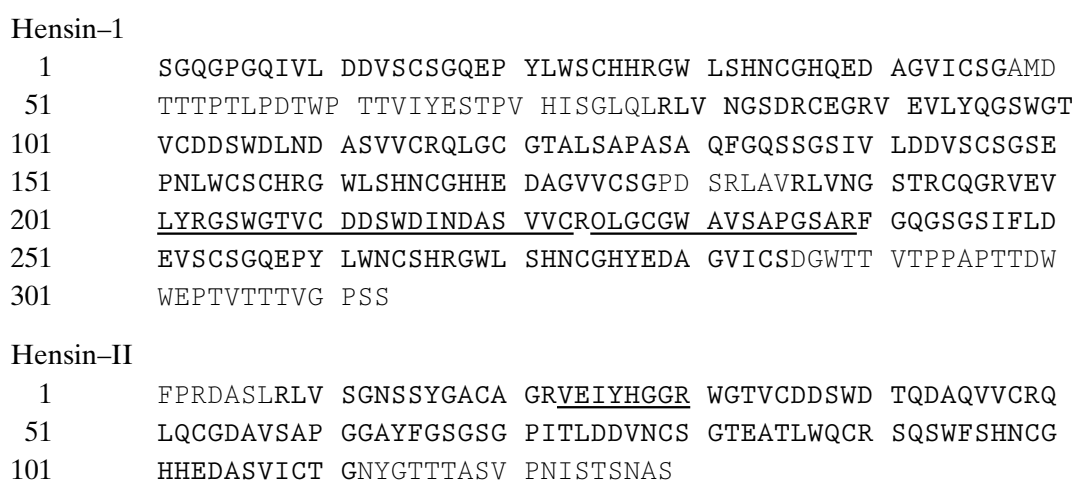

The SRCR domains are shown in bold, sequence I contains two and a half domains while sequence II contains only one SRCR domain. Underlined sequences represent sequences identified by peptide sequence of proteolytic fragments. The fused recombinant protein was generated to amino acid 1-219. The nucleotide sequences of the two clones have been deposited in the GenBank database and have an accession number of U69143 for hensin-I and U69144 for hensin-II.

Several peptides were obtained from a tryptic digest of the purified hensin and their partial amino acid sequence determinations revealed that this protein was a new member of the SRCR family of proteins $(15,16)$. Seven of nine peptide sequences were similar to the SRCR consensus motif (Table I). Homology search of the databases showed that these hensin peptides had 50-70\% homology to WC 1.1., a differentiation marker of $\mathrm{CD}^{-}, \mathrm{CD}^{-}$bovine $\mathrm{T}$ cells (23). Two other peptides had unique sequences without significant homology $(<30 \%)$ to other reported proteins.

Cloning of a partial cDNA of hensin. RT-PCR allowed us to clone 700-bp and 400-bp DNA fragments of hensin using a pair of degenerate primers designed from the peptide sequences described above (Fig. $2 A$ ). Using the sequence of this fragment we cloned two additional cDNAs. The deduced amino acid sequence of two of the cDNA clones is shown in Table II. Sequence of hensin-I includes two and a half SRCR domains each about 100 amino acids long (shown as bold letters). This sequence includes all of the 700 nucleotides of the PCR fragment. The SRCR domains in this fragment are $83 \%$ identical to each other. Hensin-II contains one complete SRCR motif which is $65 \%$ identical to those in hensin-I. These domains are separated by short unique intervening sequences. Importantly, the two sequences deduced from DNA include three peptides previously identified by sequence of the purified protein demonstrating that these sequences are authentic hensin sequences and not another homologous SRCR protein.

The 31-kD recombinant fusion protein (from the 700-bp DNA, representing aa 1-219 in hensin-I) was purified using its inserted histidine tag from an E. coli expression system and used to generate polyclonal antibodies. These antibodies recognized the $31-\mathrm{kD}$ fusion protein. They also stained a $230-\mathrm{kD}$ band, the same molecular weight of purified hensin, in the extracellular matrix of clone $\mathrm{C}$ plated at high density (Fig. $2 \mathrm{~B}$ ). A combination of immunoprecipitation followed by Western blotting of rabbit kidney showed a $230-\mathrm{kD}$ band in the cortex, medulla, and papilla with the papilla showing the highest expression (Fig. $2 \mathrm{~B}$ ). Direct Western blotting without prior immunoprecipitation detected the protein in rabbit kidney medulla and papilla, but not cortex, probably reflecting the low abundance in the cortex (data not shown). As will be demon- strated below, the only structures that stain with these antibodies were the collecting tubules. Northern blotting, performed using the mixture of 400 and 700 bp DNA cloned by RT-PCR, detected a single species in poly $\mathrm{A}^{+}$fractions of clone $\mathrm{C}$, rabbit kidney cortex, medulla, and papilla (Fig. 3). The size of the single message of $6-\mathrm{kb}$ is compatible with its coding for a $230-\mathrm{kD}$ protein. These results suggest that the sequences obtained from the purified proteins, antibodies, and DNA probes will be useful reagents in examining the role of hensin in the biology of intercalated cells.

Expression of hensin in different tissues. Using Northern analysis, we extracted RNA from a variety of epithelial and nonepithelial rabbit tissues. Cardiac and skeletal muscle did not express hensin. Several epithelia expressed hensin, with the intestine showing the highest expression (Fig. 4). The stomach, liver, and kidney cortex had a moderate level of expression but the lung had the lowest.

A role for hensin in the in vitro reversal of polarity. To document the role of hensin in the conversion of epithelial polarity of intercalated cells, clone $\mathrm{C}$ was seeded on filters at high den-
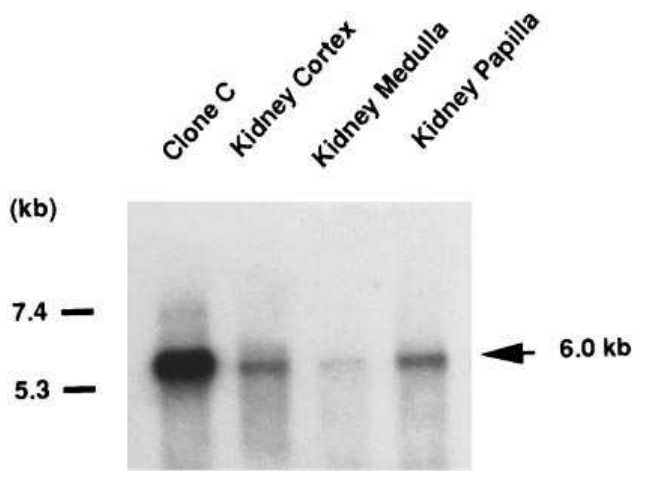

Figure 3. Expression of hensin transcript in rabbit kidney cortex, medulla, and papilla. Poly $\mathrm{A}^{+}$RNA $(1 \mu \mathrm{g})$ was purified from clone $\mathrm{C}$ and the frozen rabbit kidney and processed for northern blotting for hybridization under high stringency to a mixture of 700-bp and 400-bp cDNA probe cloned by RT-PCR. Signals were detected by autoradiography. 


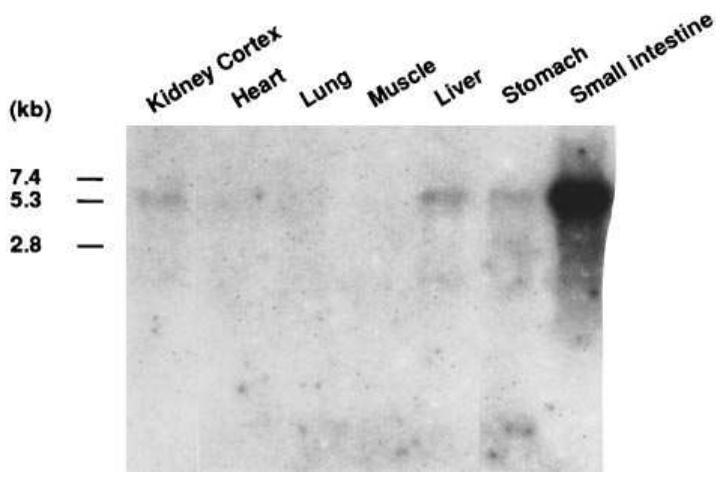

Figure 4. Expression of hensin transcripts in various tissues. Poly $\mathrm{A}^{+}$ RNA $(0.5 \mu \mathrm{g})$ was purified from rabbit tissues and processed for Northern hybridization under high stringency using a 400-bp cDNA probe cloned by RT-PCR. Signals were detected by autoradiography.

sity and cultured for $8 \mathrm{~d}$. The media contained preimmune or immune anti-hensin sera at a dilution of 1:1000 or 1:100, which were replaced with fresh media on days 2 and 5. Apical endocytosis of horseradish peroxidase was then measured as the difference between uptakes at $37^{\circ} \mathrm{C}$ and $4^{\circ} \mathrm{C}$ as described previously (14). The results are shown in Fig. 5, and demonstrate that the antibodies inhibited the apical endocytosis even at high dilution. These results suggest that hensin is an important component of the protein(s) needed for the density dependent conversion of the polarity of intercalated cells in vitro.

Hensin is a secreted protein. Clone $\mathrm{C}$ cells were plated at high density on a filter, labeled with $\left[{ }^{35} \mathrm{~S}\right] \mathrm{methionine}$, and the

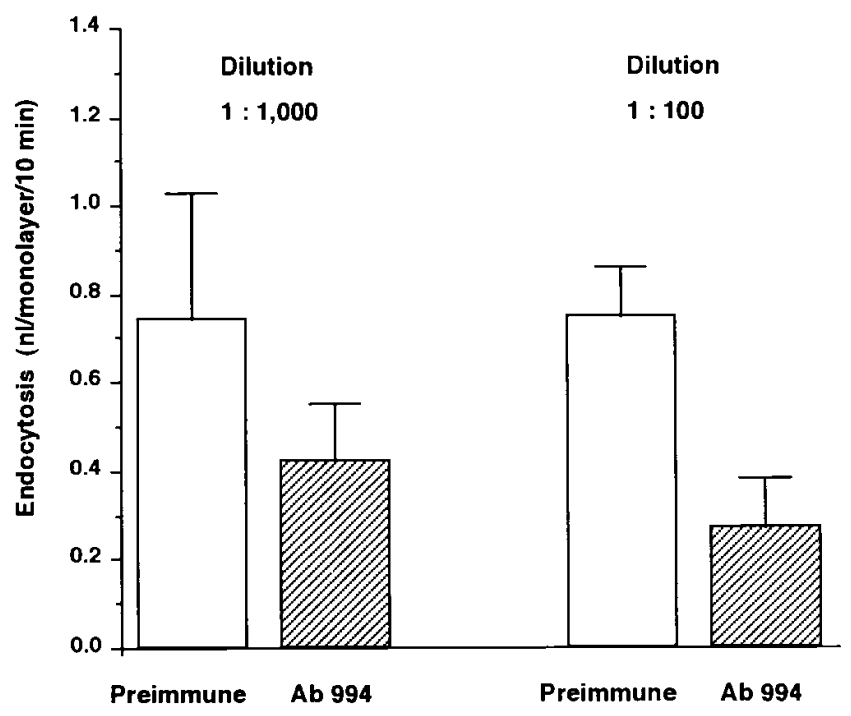

Figure 5. Antihensin antibody blocks the induction of apical endocytosis of clone $\mathrm{C}$. The culture medium was diluted with preimmune or antihensin guinea pig sera (Ab 994) at 1:100 or 1:1,000 and sterilized. Clone $\mathrm{C}$ was suspended in the medium, seeded on a filter at high density, and cultured for $8 \mathrm{~d}$ to allow the formation of tight monolayers. The medium was replaced with fresh media on day 2 and 5. Apical endocytosis of horseradish peroxidase was defined as the difference between uptakes at $37^{\circ} \mathrm{C}$ and $4^{\circ} \mathrm{C}$. The activity of horseradish peroxidase was determined by measuring the initial rate of hydrolysis of $o$-dianisidine photometrically, and converted into the volume of endocytosis. The activity at $4^{\circ} \mathrm{C}$ was $0.15 \pm 0.04 \mathrm{nl} /$ monolayer $/ 10 \mathrm{~min}$. For each column, the error bar represent standard deviation, $n=3$.
A

B
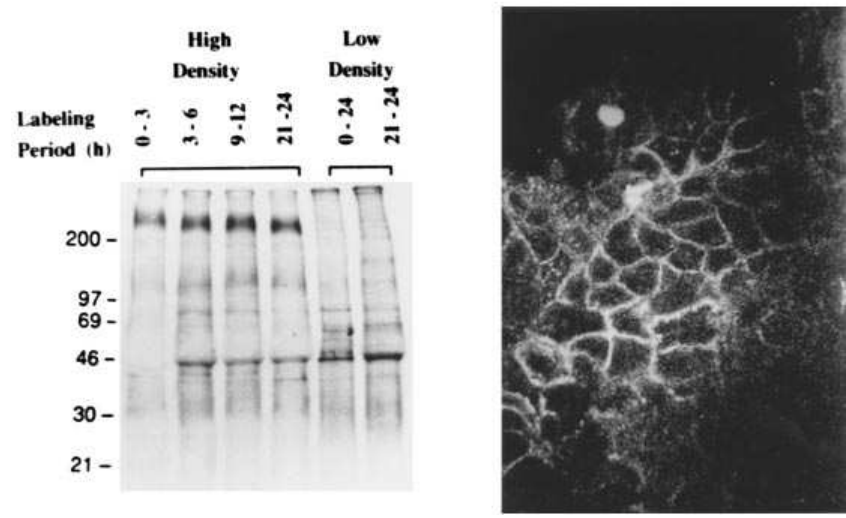

Figure 6. Cell density dependent appearance of hensin in the ECM of clone $\mathrm{C}(A)$ and indirect immunofluorescence of hensin in clone $\mathrm{C}$ $(B)$. $(A)$, Clone $\mathrm{C}$ was seeded on a filter at high or low density and labeled with $100 \mu \mathrm{Ci} / \mathrm{ml}\left[{ }^{35} \mathrm{~S}\right]$ methionine for indicated time points. The ECM fraction was prepared, dialyzed against PBS overnight, immunoprecipitatead with hensin antiserum (dilution 1:50), recovered with protein A beads. The proteins were separated by SDS-PAGE, dried and visualized by autoradiography. $(B)$ Clone $C$ was seeded on a filter at high density and cultured for $2 \mathrm{~d}$. The cells were fixed with $100 \%$ methanol, and incubated with anti hensin IgG (dilution 1:20). Signal was detected with FITC-labeled anti-guinea pig IgG. The image was photographed with a confocal laser scanning microscope. No staining was observed with preimmune serum. $\times 400$.

ECM was extracted and subjected to immunoprecipitation. As early as $3 \mathrm{~h}$ after plating, hensin was found in the ECM and the amount gradually increased up to $24 \mathrm{~h}$ (Fig. $6 \mathrm{~A}$ ). In contrast, hensin was not observed in the low density ECM even after $24 \mathrm{~h}$ after plating. These results confirm our previous observation that the $230-\mathrm{kD}$ protein appeared only in the ECM of high density cells (14). Immunocytochemistry of clone $C$ was performed to determine the subcellular localization of hensin. The confocal image of hensin staining in clone $\mathrm{C}$ plated at high density showed basolateral localization with small vesicles in the cytoplasm (Fig. $6 \mathrm{~B}$ ).

The basolateral localization rather than a purely basal ECM type of staining raised the question of whether hensin might be a membrane protein. We prepared a postnuclear membrane fraction from clone $\mathrm{C} 6 \mathrm{~d}$ after seeding at high density by centrifugation at $100,000 \mathrm{~g}$. By immunblots, more than $60 \%$ of hensin in this membrane fraction was released into the supernatant by shearing force alone, a process accelerated by the use of $100 \mathrm{mM} \mathrm{Na}_{2} \mathrm{CO}_{3}$, but not by $1 \mathrm{M} \mathrm{KCl}$ or $1 \mathrm{M} \mathrm{KSCN}$. That alkaline solutions extracted more than $90 \%$ of hensin from the membrane eliminated the possibility that hensin was an integral membrane protein (data not shown).

To test whether hensin is a secreted protein, clone $\mathrm{C}$ was seeded at high density for $6 \mathrm{~d}$ by which time they formed tight monolayers. Cells were radiolabeled with $\left[{ }^{35} \mathrm{~S}\right] \mathrm{methionine}$, chased for $3 \mathrm{~h}$, and the whole cell extracts, the apical and basolateral media were immunoprecipitated (Fig. 7). The results showed that clone $\mathrm{C}$ plated at high density secreted hensin basolaterally, suggesting that hensin was secreted and bound to the basolateral membrane or the ECM. 


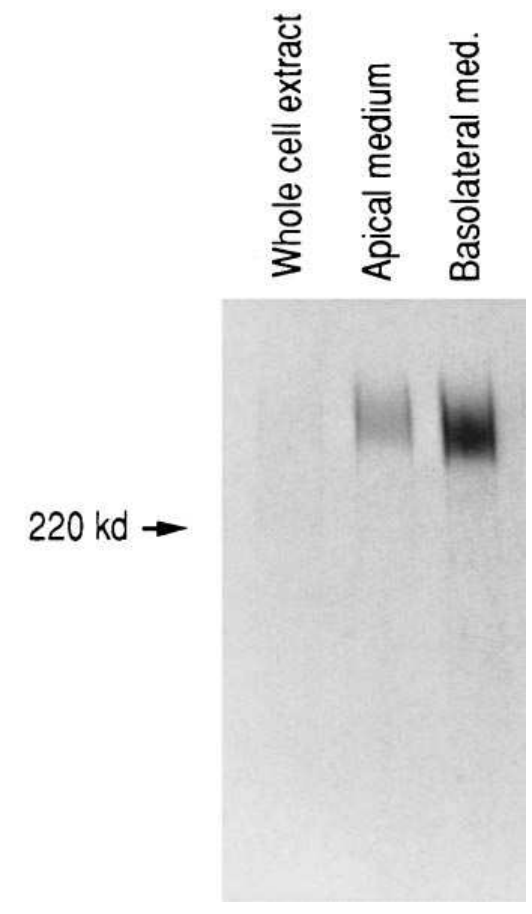

Figure 7. Polarized secretion of hensin into the basolateral medium in culture. Clone $\mathrm{C}$ was seeded on a filter at high density and cultured for $6 \mathrm{~d}$, labeled with $50 \mu \mathrm{Ci} / \mathrm{ml}\left[{ }^{35} \mathrm{~S}\right] \mathrm{me}$ thionine for $3 \mathrm{~h}$, then chased for $3 \mathrm{~h}$ with a normal medium plus 10 $\mathrm{mM}$ cold methionine.

After the apical and basolateral medium were taken off, cells were scraped and extracted with $1 \%$ SDS, $1 \%$ Triton X-100, $1 \mathrm{mM}$ EDTA and $10 \mathrm{mM}$ Tris- $\mathrm{HCl}$ (pH 8.0). The extract was diluted 10fold with $1 \mathrm{mM}$ EDTA and $10 \mathrm{mM}$ Tris- $\mathrm{HCl}$ (pH 8.0). The whole cell extract, apical and basolateral medium were processed for im-

munoprecipitation with hensin antiserum (dilution 1:500). The immunoprecipitates were separated on SDS-PAGE and dried. Signal was visualized by autoradiography.
Role of ambient $\mathrm{pH}$ in hensin production. The idea for reversal of polarity originated from the finding that feeding an acid diet caused this phenomenon. However, using the clonal intercalated cell line, we found that reducing the ambient $\mathrm{pH}$ (at least for short periods of time) had no effect on the reversal of polarity of band 3 or the induction of apical endocytosis (14). However, these cells were quite sensitive to reduction in $\mathrm{pH}$ and developed gross morphological changes when the $\mathrm{pH}$ was lowered for $3 \mathrm{~h}$ or more. To test for an effect of lowering $\mathrm{pH}$ on hensin biosynthesis, we seeded cells at high or low density for $24 \mathrm{~h}$, and then labeled the cells with $\left[{ }^{35} \mathrm{~S}\right]$ methionine for $2 \mathrm{~h}$ in the presence of low ambient $\mathrm{pH}$ ( $\mathrm{pH}$ 6.7). Media, cell extracts, and ECM were subjected to immunoprecipitation followed by SDS-PAGE and autoradiography. We found that this short period of exposure to low $\mathrm{pH}$ had no effect on the biosynthesis or secretion of hensin in low density or high density cells. Whether longer periods are required or that hensin induced polarity reversal is independent of the $\mathrm{pH}$ regulated mechanism remains to be determined.

Immunocytochemistry of hensin. We determined the localization of the protein in rabbit kidney by indirect immunofluorescence using confocal microscopy (Fig. 8). Hensin staining was restricted to the collecting tubule of kidney cortex, medulla, and papilla where it stained plasma membranes and cytoplasmic vesicles of most cells. The percentage of hensin-positive cells in the cortical collecting ducts was $82 \%$ ( 257 cells of 314 cells counted). Since intercalated cells only form a third of
Cortical Collecting Duct

Hensin (green) and PNA (red)
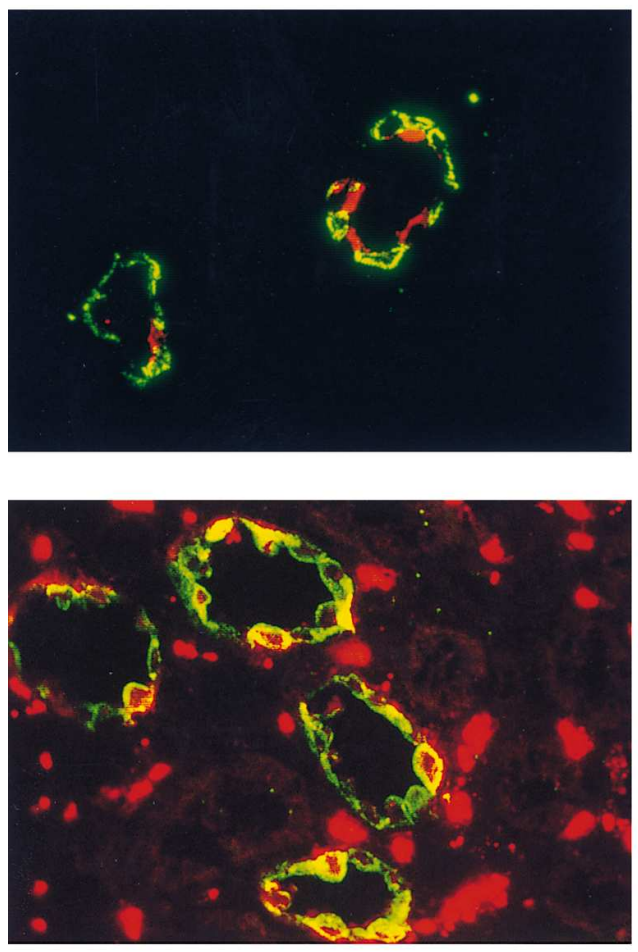

Outer Medullary Collecting Duct

Hensin (green) and Band 3 (red)
Outer Medullary Collecting Duct

Hensin (green) and $\mathrm{H}^{+}$-ATPase (red)
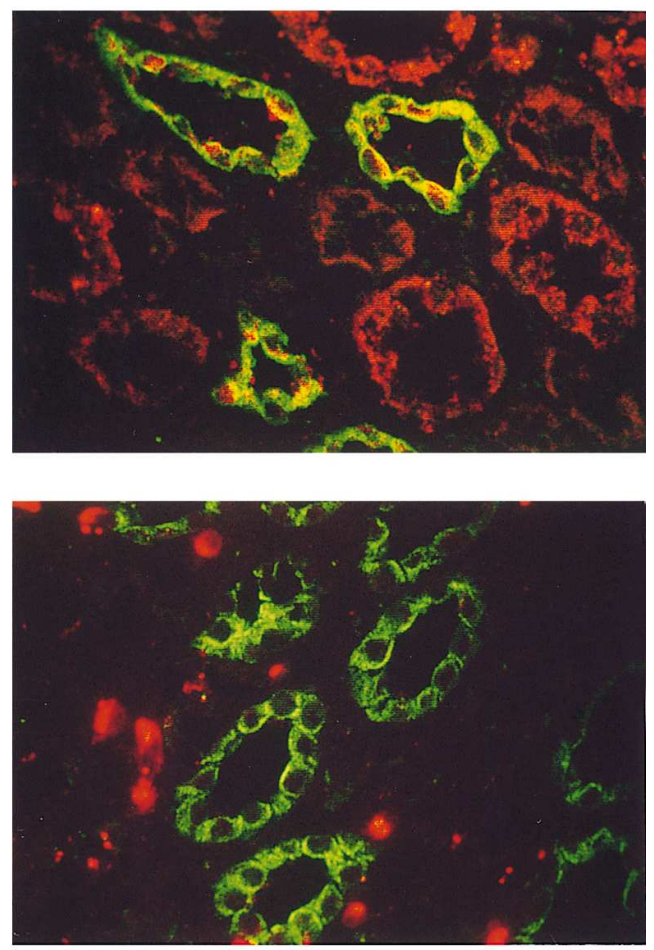

Inner Medullary Collecting Duct

Hensin (green) and Band 3 (red)
Figure 8. Subcellular localization of hensin in rabbit kidney by double immunostaining. Sections of fresh rabbit kidney were doubly stained with hensin $\mathrm{IgG}$ and TRITC-conjugated PNA, $\mathrm{H}^{+}$-ATPase antibody, or band 3 antibody. Signals were detected by FITC-conjugated secondary antibody (hensin, green) or TRITCconjugated secondary antibody $\left(\mathrm{H}^{+}\right.$-ATPase and band 3 , red) and images were photographed on a laser confocal microscope. The bright red staining outside of the collecting tubules were derived from band 3 in erythrocytes. $\times 400$. 


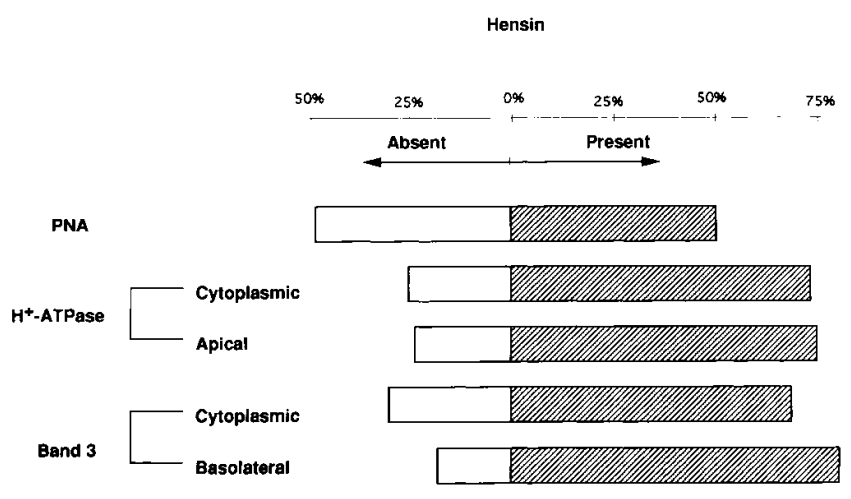

Figure 9. Subcellular distribution of hensin in the rabbit kidney intercalated cells. Rabbit kidney was doubly-stained with hensin IgG and PNA, $\mathrm{H}^{+}$-ATPase or band 3 antibody. The staining pattern of $\alpha$-intercalated cells was divided into two:diffuse cytoplasmic staining or plasma membrane staining. $\beta$-intercalated cells were identified by PNA binding. Total number of $\mathrm{H}^{+}$-ATPase-, band 3-, and PNA-positive cells were 82,148 , and 123 , respectively. Over 20 collecting tubules were randomly selected for the cell counting.

the collecting tubule cells, these results suggest that hensin also binds to the principal cells.

Kidney sections were doubly stained with hensin antibody and peanut lectin (PNA), a monoclonal $\mathrm{H}^{+}$-ATPase antibody (E11), or a monoclonal antibody for band 3 (IVF12). PNA specifically binds to the apical membrane of the $\beta$-intercalated cells of rabbit kidney cortex (21). $\mathrm{H}^{+}$-ATPase antibody (19) and band 3 antibody (20) were used for the identification of $\alpha$-intercalated cells.

$52 \%$ of PNA-positive cells (largely $\beta$-intercalated cells) were devoid of hensin staining (Fig. 9). In the subgroup of cells which expressed it, hensin was present in a basal and/or lateral location. It is noteworthy that there were some PNA positive cells that had strong lateral staining without basal staining. The remainder $(13 \%)$ of these cells showed diffuse cytoplasmic staining without clear membrane staining.

$\alpha$-Intercalated cells are characterized by apical $\mathrm{H}^{+}$-ATPase and basolateral band 3 staining, but we observed diffuse staining as well. Hence, these cells were subdivided into two classes each and analyzed separately for hensin staining. Most of the cells with apical $\mathrm{H}^{+}$-ATPase or basolateral band 3 staining were hensin positive; ( $75 \%$ of the former and $80 \%$ of the latter). Similarly, those with diffuse ATPase and band 3 staining also had hensin staining ( $73 \%$ and $69 \%$ respectively). Thus the vast majority of $\alpha$ type intercalated cells expressed hensin while half of the typical $\beta$ cells did not. The medullary and cortical intercalated cells were quite similar in the distribution of hensin negative and positive cells, hence the data were combined and presented in Fig. 9.

In the outer medulla, almost all of the intercalated cells have some form of $\alpha$ staining pattern and there were no recognizable $\beta$ - intercalated cells. The staining pattern of hensin in medullary intercalated cells differed from that in the cortex by having a brighter intensity. In addition, there were some $\alpha$-intercalated cells with the hensin staining in the apical pole (Fig. 8). This was confirmed by the overlap of hensin staining with the apical $\mathrm{H}^{+}$-ATPase staining. A small percentage of $\alpha$-cells did not stain with hensin antibodies.

In inner medullary collecting ducts, hensin antibody stained many cells in their apical pole (Fig. 8). The staining pattern appears to be rather uniform. There was no $\mathrm{H}^{+}$-ATPase-positive nor band 3-positive cells, confirming the results of others (3).

\section{Discussion}

The SRCR motif, originally found in the macrophage scavenger receptor is a 110 amino acid stretch that contains 6 or 8 cysteine residues predicted to form $\beta$ sheets by intramolecular disulfide bonds $(15,16)$. Proteins that contain these domains include both secreted (24) and membrane spanning proteins $(25,26)$. Many are involved in cell:cell recognition (e.g., CD5, CD6, WC1.1,) or immune functions (complement factor I). Hensin is most similar to WC1.1 a bovine T cell membrane protein with a similar molecular mass though with a smaller message size ( $4.5 \mathrm{vs}$. $6.0 \mathrm{~kb}$ for hensin). While the function of the SRCR domain is unknown, recent studies have identified the "receptor" for one of the CD6 SRCR domains as the activated leukocyte cell adhesion molecule (27). Hence, these domains may mediate protein:protein interaction.

Our biochemical studies have shown that while hensin is bound to membranes, it is easily released by alkali treatment. Further, pulse chase analysis demonstrated that it is secreted to the basolateral medium. While this is compatible with its being a secreted extracellular matrix protein, its immunolocalization differs from typical ECM proteins like collagen and laminin. ECM proteins are strictly basal in distribution while hensin is present in the lateral membrane as well. The images of Figs. $6 B$ and 8 resemble more those of cell adhesion molecules such as E-cadherin (28). Hence, the function of hensin is more likely to mediate cell to cell interaction rather than purely cell substrate interactions, however the two are not mutually exclusive. It is interesting in this regard, that the protein's function was manifest when the cells were plated at high cell density, an experimental paradigm of increased cell to cell interaction. That the cloned fragment contained two SRCR domains and the polyclonal antibody blocked its function suggests that the SRCR domains might be involved in these interactions. However, more direct experiments will need to be performed.

Our previous studies demonstrated that hensin is directly involved in the conversion of the polarity of the clonal intercalated cell line. Its localization in the ECM fraction of high density cells $(\alpha$-like) was the determining factor in that cell's phenotype. In low density cells ( $\beta$-like), no hensin was seen in the ECM, but plating these cells on hensin-conditioned filters reversed their polarity. Although it is premature to conclude whether it has a similar function in the acidosis-induced plasticity of these cells in vivo, some findings are intriguing enough to warrant a few speculations. It is now well-established that intercalated cells have heterogenous patterns of staining with $\mathrm{H}^{+}$-ATPase, band 3 antibodies and in PNA binding. Hensin staining is also heterogenous. As many as half of the PNA binding cells ( $\beta$ type) do not have hensin in their intercellular space or ECM, reminiscent of the low density cells. This is in contrast to those with apical $\mathrm{H}^{+}$-ATPase or basolateral band 3 ( $\alpha$ type), where most of the cells, like the high density cells express hensin in their ECM (Fig. 8). A more refined analysis will need to be performed where the pattern of subcellular expression of hensin will have to be correlated with that of the ATPase and the anion exchanger, especially of how this pattern changes in response to feeding an acid diet. We had re- 
cently suggested that the multiplicity of patterns shown for $\mathrm{H}^{+}$-ATPase or band 3 localization (29) indicates that a large number of intermediate forms exist in a spectrum of types from $\alpha$ to $\beta$. Examination of the pattern of expression of these four proteins (hensin, band 3, the ATPase, and PNA binding protein) might help to provide a more solid foundation for the acidosis-induced plasticity hypothesis.

In our preliminary studies on hensin expression we noted that hensin is synthesized and deposited in the ECM of high density cells immediately after plating (14). The half life of hensin was very long in high density ECM. However, it appeared that it was no longer synthesized after the cells were plated for one week or more. Two conclusions can be drawn from this; one that hensin has the property of a molecular switch, i.e., it is "turned on" and remains "on," with no necessity of further synthesis. Another, is that if it was going to be "turned off," it would have to be degraded. Hence, proteases and protease inhibitors are likely to be important regulators of its function. It is also intriguing that some cells (both $\beta$ and $\alpha$ types) do not have hensin in their ECM. Was it produced and then degraded? Clearly more work needs to be done in this area.

Hensin was expressed in most collecting tubule cells suggesting that the principal cells also express it. Its function in these cells is unknown at present. Nor does this expression shed any light on an intrgiuing hypothesis that Fejes-Toth and Naray-Fejes-Toth (30) had proposed, that the $\beta$-intercalated cells can give rise to principal cells and $\alpha$ cells. Based on the developmental expression of a series of markers, Minuth and his co-workers (31) have suggested that all three cell types originate from one precursor ureteric bud cell type. This is the most likely hypothesis, but it would be important to test the other hypothesis directly by using either clonal cell lines or by marking a single ureteric bud cell and examining its progeny.

\section{Acknowledgments}

We are grateful to S. Gluck for monoclonal antibody E11, M.L. Jennings for monoclonal antibody IVF12. J. Takito is indebted to Y. Tanabe for continued advice.

This work was supported by grant DK-20999 from the National Institutes of Health.

\section{References}

1. Steinmetz, P.R. 1986. Cellular organization of urinary acidification. Am. J. Physiol. 251:F173-F187.

2. Al-Awqati, Q., and R. Beauwens. 1992. Cellular mechanisms of $\mathrm{H}^{+}$and $\mathrm{HCO}_{3}^{-}$transport in tight urinary epithelia. In Renal Physiology. Volume 1. E.E. Windhager editor. Oxford University Press, New York. 323-350.

3. Schuster, V.L. 1993. Function and regulation of collecting duct intercalated cells. Annu. Rev. Physiol. 55: 267-288.

4. Madsen, K.M., and C.C. Tisher. 1983. Structural functional relationships along the distal nephron. Am. J. Physiol. 19:F1-F9.

5. Schwartz, G., J. Barasch, and Q. Al-Awqati. 1985. Plasticity of functional epithelial polarity. Nature (Lond.). 318:368-371.

6. Drenckhahn, D., K. Schluter, D.P. Allen, and V. Bennett. 1985. Colocalization of band 3 with ankyrin and spectrin at the basal membrane of intercalated cells in rat kidney. Science (Wash. DC). 230:1287-1289.

7. Alper, S.L., J. Natale, S. Gluck, H.F. Lodish, and D. Brown. 1989. Subtypes of intercalated cells in rat kidney collecting duct defined by antibodies against erythroid band 3 and renal vacuolar $\mathrm{H}^{+}$-ATPase. Proc. Natl. Acad. Sci. USA. 86:5429-5433.
8. Brown, D., S. Hirsch, and S. Gluck. 1988. An $\mathrm{H}^{+}$-ATPase in opposite plasma membrane domains in kidney epithelial cell subpopulations. Nature (Lond.). 331:622-624.

9. Verlander, J.W., K.M. Madsen, J.K. Cannon, and C.C. Tisher. 1994. Activation of acid-secreting intercalated cells in rabbit collecting duct with ammonium chloride loading. Am. J. Physiol. 266:F633-645.

10. Bastani, B., H. Purcell, P. Hemken, D. Trigg, and S. Gluck. 1991. Expression and distribution of renal vacuolar proton translocating adenosine triphosphatase in response to chronic acid and alkali loads in the rat. J. Clin. Invest. 88:126-136.

11. Van Adelsberg, J.S., J.C. Edwards, D. Herzlinger, C. Cannon, M. Rater, and Q. Al-Awqati. 1989. Isolation and culture of $\mathrm{HCO}_{3}$ secreting intercalated cells. Am. J. Physiol. 256:C1004-C1011.

12. Edwards, J.C., J.S. van Adelsberg, M. Rater, D.A. Herzlinger, J. Lebowitz, and Q. Al-Awqati. 1992. Conditional immortalization of bicarbonatesecreting intercalated cells from rabbit. Am. J. Physiol. 263:C521-C529.

13. Van Adelsberg, J.S., J.C. Edwards, and Q. Al-Awqati. 1993. The apical $\mathrm{Cl} / \mathrm{HCO}_{3}$ exchanger of $\beta$ intercalated cells. J. Biol. Chem. 268:11283-11289.

14. Van Adelsberg, J., J.C. Edwards, J. Takito, B. Kiss, and Q. Al-Awqati. 1994. An induced extracellular matrix protein reverses the polarity of band 3 in intercalated epithelial cells. Cell. 76:1053-1061.

15. Freeman, M., J. Ashkenas, D.J.G. Rees, D.M. Kingsley, N.G. Copeland, N.A. Jenkins, and M. Krieger. 1990. An ancient, highly conserved family of cysteine-rich protein domains revealed by cloning type I and type II murine macrophage scavenger receptors. Proc. Natl. Acad. Sci. USA. 87:8810-8814.

16. Resnick, D., A. Pearson, and M. Krieger. 1994. The SRCR Superfamily: a family reminiscent of the Ig superfamily. Trends Biochem. Sci. 19:5-8.

17. Harlow, E., and D.P Lane. 1988. Antibodies: A Laboratory Manual. Cold Spring Harbor Laboratory Press, Cold Spring Harbor, New York. 471510 .

18. Sambrook, J., E.F. Fritsch, and T. Maniatis. 1989. Molecular Cloning: A Laboratory Manual. Cold Spring Harbor Laboratory Press, Cold Spring Harbor, New York.

19. Yurko, M.A., and S. Gluck. 1987. Production and characterization of a monoclonal antibody to the vacuolar $\mathrm{H}^{+}$-ATPase of renal epithelia. J. Biol. Chem. 262:15770-15779.

20. Jennings, M.L., M.P. Anderson, and R. Monaghan. 1986. Monoclonal antibodies against human erythrocyte band 3 protein: localization of proteolytic cleavage sites and stilbenedisulfonate-binding lysine residues. J. Biol. Chem. 261:9002-9010.

21. LeHir, M., B. Kaissling, B.M. Koeppen, and J.B. Wade. 1982. Binding of peanut lectin to specific cell types in kidney. Am. J. Physiol. 242:C117-C120.

22. Romano, V., M. Hatzfeld, T.M. Magin, R. Zimbelman, W.W. Franke, G. Maier, and H. Ponstingl. 1986. Cytokeratin expression in simple epithelia. I. Identification of mRNA coding for human cytokeratin no. 18 by a cDNA clone. Differentiation. 30:244-253.

23. Wijngaard, P.L.J., M.J. Metzelaar, N.D. MacHugh, W.I. Morrison, and H.C. Clevers. 1992. Molecular chracterization of the WC1 antigen expressed specifically on bovine $\mathrm{CD}^{-} \mathrm{CD}^{-} \gamma \delta \mathrm{T}$ lymphocytes. J. Immunol. 149:32733277.

24. Ullrich, A., I. Sures, M. D’Egidio, B. Jallal, T.J. Powell, R. Herbst, A. Dreps, M. Azam, M. Rubinstein, C. Natoli et al. 1994. The secreted tumor-associated antigen $90 \mathrm{~K}$ is a potent immune stimulator. J. Biol. Chem. 269:1840118407.

25. Chicheportiche, Y., and P. Vassalli. 1994. Cloning and expression of a mouse macrophage cDNA coding for a membrane glycoprotein of the scavenger receptor cysteine-rich domain family. J. Biol. Chem. 269:5512-5517.

26. Elomaa, O., M. Kangas, C. Sahlberg, J. Tuukkanen, R. Sormunen, A. Liakka, I. Thesleff, G. Kraal, and K. Tryggvason. 1995. Cloning of a novel bacteria-binding receptor structurally related to scavenger receptors and expressed in a subset of macrophages. Cell. 80:603-609.

27. Whitney, G.S., G.C. Starling, M.A. Bowen, B. Modrell, A.W. Siadak, and A. Aruffo. 1995. The membrane-proximal scavenger receptor cysteine-rich domain of CD6 contains the activated leukocyte cell adhesion molecule binding site. J. Biol. Chem. 270:18187-18190.

28. Kemperman, H., Y. Wijnands, J. Wesseling, C.M. Niessen, A. Sonnenberg, and E. Roos. 1994. The mucin epiglycanin on TA3/Ha carcinoma cells prevents $\alpha_{6} \beta_{4}$-mediated adhesion to laminin and kalinin and E-cadherin-mediated cell-cell ineraction. J. Cell Biol. 127:2071-2080.

29. Al-Awqati, Q. 1996. Plasticity in epithelial polarity of renal intercalated cells: targeting of the $\mathrm{H}^{+}$-ATPase and band 3. Am. J. Physiol. 39:C1571-1580.

30. Fejes-Toth, G., and A. Naray-Fejes-Toth. 1992. Differentiation of renal $\beta$-intercalated cells to $\alpha$-intercalated and principal cells in culture. Proc. Natl. Acad. Sci. USA. 89:5487-5491.

31. Minuth, W.W., P. Gilbert, U. Rudolph, and W.S. Spielman. 1989. Successive histochemical differentiation steps during postnatal development of the collecting duct of rabbit kidney. Histochemistry. 93:19-25. 